\title{
Previous Open Stone Surgery: Is It a Risk Factor for Bleeding in Percutaneous Nephrolithotomy
}

\author{
Perkütan Nefrolitotomide Kanama: Daha Önce Açık Taş Cerrahisi Geçirmiş Olmak \\ Bir Risk mi?
}

\author{
(D) Tufan Süelözgen, (D) Yusuf Özlem İlbey \\ University of Health Sciences, Izmir Tepecik Training and Research Hospital, Clinic of Urology, Izmir, Turkiye
}

\section{What's known on the subject? and What does the study add?}

Although there are many reports examining the effects of previous open stone surgery on percutaneous nephrolithotomy, its possible effects on bleeding in percutaneous nephrolithotomy is still controversial in the literature.

\begin{abstract}
Objective: The aim of this study is to determine whether previous open stone surgery is a risk factor for bleeding in patients undergoing percutaneous nephrolithotomy (PNL).

Materials and Methods: Data of patients who underwent PNL in our clinic between 2007 and 2015 were reviewed retrospectively. Eighty-two patients underwent PNL and had a history of previous ipsilateral open surgery. A control group was created with 82 patients randomly selected among PNL patients with no history of open surgery. The groups were evaluated in terms of preoperative demographic data, operative success and complications, especially hemorrhage requiring transfusion.

Results: The groups were similar in terms of demographic data and stone burden. One patient of each group was administered intraoperative blood transfusion. There was no statistically significant difference between the two groups in terms of postoperative blood transfusion ( $p=0.245$ ).

Conclusion: In our study, it can be said that previous open stone surgery does not increase potential complication of bleeding in PNL.

Keywords: Percutaneous nephrolithotomy, Open stone surgery, Bleeding
\end{abstract}

\section{Öz}

Amaç: Bu çalışmanın amacı perkütan nefrolitotomi (PNL) yapılan hastalarda daha önce açık taş cerrahisi geçirmenin kanama için bir risk faktörü olup olmadığını belirlemektir.

Gereç ve Yöntem: 2007-2015 yılları arasında kliniğimizde PNL yapılan hastaların verileri geriye dönük olarak incelendi. PNL yapılan ve aynı taraftan daha önce açık operasyon öyküsü olan 82 hasta mevcuttu. PNL yapılıp, açık operasyon öyküsü olmayan hastalardan randomize olarak 82 hasta seçildi ve kontrol grubu oluşturuldu. Preoperatif demografik veriler, operasyon başarısı ve özellikle transfüzyon gerektiren kanama ve diğer komplikasyonlar açısından gruplar değerlendirildi.

Bulgular: Gruplar demografik veriler ve taş yükü açısından birbirine benzerdi. Her iki grupta birer hastaya intraoperatif kan transfüzyonu yapıldı. Postoperatif kan transfüzyonu açısından gruplar arasında istatistiksel olarak fark saptanmadı $(p=0,245)$.

Sonuç: Çalışmamızda daha önce açık taş cerrahisi geçirmiş olmanın PNL'de kanama komplikasyonu ihtimalini artırmadığından bahsedilebilir.

Anahtar Kelimeler: Perkütan nefrolitotomi, Açık taş operasyonu, Kanama

Correspondence: Tufan Süelözgen MD, University of Health Sciences, İzmir Tepecik Training and Research Hospital, Clinic of Urology, Izmir, Turkiye E-mail: tsuelozgen@hotmail.com ORCID-ID: orcid.org/0000-0003-0790-3926

Received: 02.06.2018 Accepted: 26.06.2018

Cite this article as: Süelözgen T, İlbey YÖ. Previous Open Stone Surgery: Is It a Risk Factor for Bleeding in Percutaneous Nephrolithotomy? J Urol Surg 2018;5(3):154-157.

बCopyright 2018 by the Association of Urological Surgery / Journal of Urological Surgery published by Galenos Publishing House. 


\section{Introduction}

Percutaneous nephrolithotomy (PNL) is a minimally invasive surgical procedure considered the first choice in the treatment of kidney stones larger than $2 \mathrm{~cm}$ (1). Despite appropriate surgical and medical treatment, stone disease can recur in about half of the cases within 5-7 years (2). In this situation, PNL may be required in patients who underwent open stone removal in the past. Perinephric scar tissue, calyceal scarring, and distortion due to the previous surgery have been reported to affect subsequent interventions (3). Although there are many reports examining the effects of previous open stone surgery on PNL, its possible effects on bleeding in PNL is still controversial in the literature. In our study, we examined if previous open stone surgery would increase the risk of bleeding in PNL or not.

\section{Materials and Methods}

The patients included in the study were retrospectively evaluated and divided into two groups and written informed consent was obtained from all patients. Eighty-two patients, who underwent PNL and had previous ipsilateral open stone surgery between 2007 and 2015, were included in group 1. Data on age, gender, duration of operation, duration of fluoroscopy, and bleeding requiring intraoperative transfusion were noted. Postoperative complications were also noted. For the control group, group 2, 82 patients were randomly selected from PNL patients who did not have open stone surgery before. All patients were evaluated with non-contrast computed tomography (CT) preoperatively. PNL was decided with respect to stone size or after unsuccessful extracorporeal shockwave lithotripsy. The number of open stone surgeries the patients underwent could not be obtained accurately from the records due to the retrospective design of our study.

Isolated renal pelvis or isolated calyx stones were classified as simple stones; pelvis and calyx stones or staghorn stones as complex stones. Patients with positive bacterial culture were treated with appropriate antibiotics. All patients underwent operation when their urine cultures were sterile.

Procedurally, the patients were placed in the lithotomy position under general anesthesia. Using a $26 \mathrm{~F}$ cystoscope, a 6 F ureteral catheter was inserted. The patient was then turned to the prone position and contrast medium was administered through the urethral catheter. An $18 \mathrm{G}$ access needle was introduced into the collecting system through the selected calyx under fluoroscopy. A guide wire was introduced after clear urine flow was observed. Following $6 \mathrm{~F}$ dilation with Amplatz dilator, tract was created in accordance with the single step technique using 25-30 F dilator. We had no patients in whom access failed. The stones were fragmented using a $27 \mathrm{~F}$ nephroscope and an ultrasonic lithotripter. A $14 \mathrm{~F}$ Malecot catheter was placed postoperatively in all patients. In patients without complications, the Malecot catheter was removed on postoperative day 1-3. All patients were re-evaluated with non-contrast tomography after postoperative month 1. Detecting no stones or some small stone fragments $\leq 4 \mathrm{~mm}$ was recognized as success.

\section{Statistical Analysis}

Summary statistics were used for continuous variables (mean, standard deviation, standard error). Associations between categorical variables were analysed using $\chi^{2}$ test. When the expected number of observations in one or more categories was $\leq 5$, we used the Fisher's exact test. The independent-samples $\mathrm{t}$-test and the Mann-Whitney $\mathrm{U}$ test were used to compare differences between two independent groups. Data were analyzed using SPSS version 15.0 software (SPSS Inc., Chicago, United States of America). A p value of less than 0.05 was considered statistically significant.

\section{Results}

Of the 82 patients in group 1, $47(57.3 \%)$ were male and 35 $(42.7 \%)$ were female, with a mean age of $48.2 \pm 14.0$ years. The mean operative time was $102 \pm 266$ minutes and the mean duration of fluoroscopy was $230 \pm 294$ seconds. Fortytwo patients had simple stones (51.2\%) while $40(48.8 \%)$ had complex stones.

In group 2, 46 (56.1\%) of 82 patients were male and 36 (43.9\%) were female, with a mean age of $44.05 \pm 17$ years. The mean duration of operation was $134 \pm 44$ minutes and the mean duration of fluoroscopy was $194 \pm 44$ seconds. In group 2, $43(52.4 \%)$ patients had simple and $39(47.6 \%)$ patients had complex stones. There was no statistically significant difference between the groups in terms of the above mentioned variables (Table 1).

Table 1. Significant demographic data

\begin{tabular}{llll}
\hline & $\begin{array}{l}\text { Group 1 } \\
(\mathbf{n = 8 2})\end{array}$ & $\begin{array}{l}\text { Group 2 } \\
(\mathbf{n = 8 2})\end{array}$ & p value \\
\hline $\begin{array}{l}\text { Mean age }( \pm \text { SD) } \\
\text { Gender }(\%)\end{array}$ & $48.24 \pm 14$ & $44 \pm 17$ & 0.96 \\
Male & $47(57.3 \%)$ & $46(56.1 \%)$ & 0.87 \\
Female & $35(42.7 \%)$ & $36(43.9 \%)$ & \\
Operation site (\%) & & & 0.92 \\
Right & $54(65.9 \%)$ & $42(51.2 \%)$ & \\
Left & $28(34.1 \%)$ & $40(48.8 \%)$ & \\
Stone burden $(\%)$ & & & 0.92 \\
Simple & $42(51.2 \%)$ & $43(52.4 \%)$ & \\
Complex & $40(48.8 \%)$ & $39(47.6 \%)$ & \\
\hline SD: Standard deviation & & & \\
\hline
\end{tabular}


Table 2. Intraoperative data and postoperative complications

\begin{tabular}{|c|c|c|c|}
\hline & $\begin{array}{l}\text { Group } 1 \\
(n=82)\end{array}$ & $\begin{array}{l}\text { Group } 2 \\
(n=82)\end{array}$ & $p$ value \\
\hline Operation time (min) & 102 & 134 & 0.17 \\
\hline Fluroscopy time (sec) & 230 & 194 & 0.36 \\
\hline Multiple access (\%) & $5(6.1)$ & $12(14.6)$ & 0.12 \\
\hline $\begin{array}{l}\text { Intraoperative blood } \\
\text { transfusion }(\%)\end{array}$ & $1(1.2)$ & $1(1.2)$ & 1 \\
\hline $\begin{array}{l}\text { Postoperative blood } \\
\text { transfusion (\%) }\end{array}$ & $3(3.6)$ & 0 & 0.24 \\
\hline Postoperative fever (\%) & $5(6.1)$ & $12(14.6)$ & 0.12 \\
\hline Operation success (\%) & $66(79.2)$ & $70(85.3)$ & 0.4 \\
\hline $\begin{array}{l}\text { Additional intervention } \\
\text { (DJS) (\%) }\end{array}$ & $2(2.4)$ & 0 & 0.24 \\
\hline
\end{tabular}

Double access was required in $5(6.1 \%)$ patients of group 1 and in $12(14.6 \%)$ patients of group $2(p=0.122)$.

Intraoperative blood transfusion was performed for one patient of each group.

Blood transfusion was performed due to postoperative hemodynamic instability in 3 patients (3.7\%) of group 1. None of the patients required transfusion in the control group and there was no statistically significant difference between the groups ( $p=0.245)$. Postoperative fever was observed in $5(6.1 \%)$ patients of group 1 and in $12(12.6 \%)$ patients of the control group. There was no difference between the groups in terms of postoperative fever $(p=0.122)$.

Double J stent was implanted in 2 patients (2.4\%) in group 1 due to prolonged wound drainage. The stents were removed one month after the operation. There was no need for additional surgical intervention in any patients.

Residual stones were observed in 17 (20.7\%) patients of group 1 and in $12(14.6 \%)$ patients of group 2 on CT performed on postoperative $1^{\text {st }}$ month. There was no significant difference between the groups in terms of operative success (Table 2).

\section{Discussion}

PNL is the first choice surgical method to be used in the treatment of kidney stones $\geq 2 \mathrm{~cm}$ in size, but complications are observed in almost one fourth of patients (23.3\%) despite developing technology and increasing experience. Post-PNL bleeding is a very common complication. Although bleeding is treated with conservative methods in most of the cases, bleeding requiring transfusion is considered a complication and has been reported at different rates (1\%-55\%) in the literature (4). Many factors predicting bleeding in PNL were examined in studies. Stone size, presence of staghorn stones, prolonged operative time and a need for multiple accesses are known to increase bleeding complication requiring post-PNL transfusion $(4,5)$. It is controversial whether previous ipsilateral open stone surgery is a risk factor for bleeding complication requiring transfusion or not. It has been reported that retroperitoneal scar tissue and pelvicalyceal structures with scars may complicate all operational stages from access to fragmentation, especially maneuvering with the nephroscope (6).

In their study comparing 65 patients with previous nephrolithotomy and 117 patients without any history of renal surgery, Basiri et al. (7) observed no difference in terms of complications including bleeding. Said et al. (8), however, stated that previous open surgery can be an important determinant for hemorrhage and transfusion requirement in PNL. Yesil et al. (9) reported that severe hemorrhages requiring angioembolization were frequent in their 42 patients who underwent open renal surgery. Sofikerim et al. (10) determined that the incidence of bleeding requiring transfusion was nearly twice as high in the group with open surgery, suggesting that this was a predisposing factor for bleeding complication.

In our study, blood transfusion was performed in one patient in group 1 and one patient in group $2(p=1)$. Postoperatively, three patients (3.6\%) of group 1 had bleeding requiring transfusion while no transfusion was required in the control group. However, the results were not found to be statistically significant $(p=0.12)$. There was no problem, such as pseudoaneurysm or arteriovenous fistula, in our patients who required angioembolization. Interestingly, there are also some reports indicating that previous open renal stone surgery reduced blood loss during PNL (11).

PNL success was stated to decrease in patients with previous open stone surgery in some studies (12). In our study, stonefree rates were $79.2 \%$ in the group with previous operation and $85.3 \%$ in the control group, and there was no statistically significant difference in success rate between the groups. Our success rates are consistent with the literature.

\section{Study Limitations}

The retrospective design, the fact that different surgeons performed the operations and relatively limited number of patients can be mentioned as the major limitations of our study.

\section{Conclusion}

Despite limited number of patients in the study, it is possible to state that previous open renal stone surgery is not a risk factor for bleeding complication requiring transfusion in PNL. However, further studies with larger patient groups are needed in order to reach definite conclusion on this issue. 


\section{Ethics}

Ethics Committee Approval: Retrospective study.

Informed Consent: It was taken.

Peer-review: Externally peer-reviewed.

\section{Authorship Contributions}

Surgical and Medical Practices: T.S., Concept: Y.Ö.I., T.S., Design: Y.Ö.I., T.S., Data Collection or Processing: Y.Ö.I., T.S., Analysis or Interpretation: Y.Ö.I., T.S., Literature Search: Y.Ö.I., T.S., Writing: T.S.

Conflict of Interest: No conflict of interest was declared by the authors.

Financial Disclosure: The authors declared that this study received no financial support.

\section{References}

1. Türk C, Knoll T. Petrik A, Sarica K, Seitz C, Straub M. Guidelines on Urolithiasis. European Association of Urolog 2011:289-326.

2. Parmar MS. Kidney stones. BMJ 2004;2:1420-1424.

3. Kamphuis GM, Baard J, Westendarp M, de la Rosette JJ. Lessons learned from the CROES percutaneous nephrolithotomy global study. World J Urol 2015;33:223-233
4. Lee JK, Kim BS, Park YK. Predictive factors for bleeding during percutaneous nephrolithotomy. Korean J Urol 2013;54:448-453.

5. Akman T, Binbay M, Sari E, Yuruk E, Tepeler A, Akcay M. Muslumanoglu AY, Tefekli A. Factors affecting bleeding during percutaneous nephrolithotomy:single surgeon experience. J Endourol 2011;25:327-333.

6. Chipde SS, Agrawal S. Retroperitoneoscopic pyelolithotomy: a minimally invasive alternative for the management of large renal pelvic stone. Int Braz J Urol 2014;40:123-124.

7. Basiri A, Karrami $H$, Moghaddam SM, Shadpour P. Percutaneous nephrolithotomy in patients with or without a history of open nephrolithotomy. J Endourol 2003;17:213-216.

8. Said SH, Al Kadum Hassan MA, Ali RH, Aghaways I, Kakamad FH, Mohammad $\mathrm{K}$. Percutaneous nephrolithotomy; alarming variables for postoperative bleeding. Arab J Urol 2017;15:24-29.

9. Yesil S, Ozturk U, Goktug HN, Tuygun C, Nalbant I, Imamoglu MA. Previous open renal surgery increased vascular complications in percutaneous nephrolithotomy (PCNL) compared with primary and secondary PCNL and extracorporeal shock wave lithotripsy patients: a retrospective study. Urol Int 2013;91:331-334.

10. Sofikerim M, Demirci D, Gülmez I, Karacagil M. Does previous open nephrolithotomy affect the outcome of percutaneous nephrolithotomy. J Endourol 2007;21:401-403.

11. Kukreja R, Desai M, Patel $S$, Bapat $S$, Desai M. Factors affecting blood loss during percutaneous nephrolithotomy: Prospective Study. J Endourol 2004;18:715-722.

12. Ozgor F, Kucuktopcu O, Sarılar O, Toptas M, Simsek A, Gurbuz ZG, Akbulut MF, Muslumanoglu AY, Binbay M . Does previous open renal surgery or percutaneous nephrolithotomy affect the outcomes and complications of percutaneous nephrolithotomy. Urolithiasis 2015;43:541-547. 